\title{
Target Definitionoforbital Embryonal Rhabdomyosarcoma (Rms) by Multimodality Imaging: An Original Article
}

\author{
FerratDincoglan $^{1^{*}, \text { Omer Sager }^{1} \text {, Selcuk Demiral }}{ }^{1}$, Murat Beyzadeoglu ${ }^{1}$ \\ ${ }^{I}$ Department of Radiation Oncology; University of Health Sciences, Gulhane Medical Faculty, Ankara, Turkey \\ *Corresponding Author: FerratDincoglan, Department of Radiation Oncology, University of Health \\ Sciences, Gulhane Medical Faculty, Ankara, Turkey
}

\begin{abstract}
Objective: Treatments strategies for orbital embryonal rhabdomyosarcoma (RMS) may include surgery, radiation therapy $(R T)$, and chemotherapy. Satisfactory survival outcomes may be achieved for orbital embryonal RMS by use of these therapies, however, adverse effects of administered treatments are major concerns regarding management given the long life expectancy of affected patients. Within this context, improving the toxicity profile of treatment has been a critical aspect of management. In terms of RT, contemporary techniques and proton therapy have been utilized for improving the therapeutic ratio. In this original article, we assessed target definition for orbital embryonal RMS with multimodality imaging.
\end{abstract}

Materials And Methods: Target definition for orbital embryonal RMS with multimodality imaging has been assessed with comparative evaluation.

Results: Precise RT planning has been performed by use of treatment planning systems at our tertiary cancer center. Optimal encompassing of treatment volumes with sparing of critical structures has been prioritized in RT planning to improve the therapeytic ratio. Definition of ground truth target volume has been done by the board certified radiation oncologists following comprehensive evaluation, colleague peer review, collaboration, and ultimate consensus to be utilized for actual treatment and for comparative assessments. Ground truth target volume has been found to be identical with target volume definition with CT-MR fusion based imaging.

Conclusion: Combined use of CT and MRI for accurate target and treatment volume determination procedure may be considered to improve the therapeutic ratio for orbital embryonal RMS management with $R T$ despite the need for further supporting evidence.

Keywords: orbital embryonal rhabdomyosarcoma (RMS), radiation therapy $(R T)$, magnetic resonance imaging (MRI)

\section{INTRODUCTION}

Although rhabdomyosarcoma (RMS) is a rare tumor among group of mesenchymal malignancies as a whole, orbital RMS constitutes the most frequent soft tissue sarcoma in the head and neck region in children [1-3]. Tissue of origin is the pluripotent mesenchyme, and the prognosis may be rather favorable, however, orbital embryonal RMS may pose a formidable challenge to the ocular oncologist in terms of diagnosis and management [1-3]. Affected patients may typically present with a rapidly enlarging mass frequuently localized in the upper inner quadrant. While pain is not a typical symptom, proptosis and diplopia may occur. Also, edema may result from invasion of the eyelid. Majority of orbital RMS are of the embryonal subtype occuring in the first decade of life.
Treatments strategies for orbital embryonal RMS may include surgery, radiation therapy (RT), and chemotherapy. Satisfactory survival outcomes may be achieved for orbital embryonal RMS by use of these therapies, however, adverse effects of administered treatments are major concerns regarding management given the long life expectancy of affected patients. Within this context, improving the toxicity profile of treatment has been a critical aspect of management. In terms of RT, contemporary techniques and proton therapy have been utilized for improving the therapeutic ratio [4-7]. In this original article, we evaluated target definition for orbital embryonal RMS with multimodality imaging.

\section{Materials AND Methods}

Target definition with multimodality imaging by incorporation of magnetic resonance imaging 
(MRI) or by computed tomography (CT)simulation images only has been assessed with comparative analysis in patients treated for orbital embryonal RMS. Ground truth target volume to be used as the reference for actual treatment and comparison purposes has been comprehensively determined by board certified radiation oncologists after meticulous evaluation, colleague peer review, collaboration, and ultimate consensus. Comprehensive patient assessment has been done including the lesion sizes, exact localizations, symptomatology, preferences, and expected outcomes of therapy. CT-simulator (GE Lightspeed RT, GE Healthcare, Chalfont St. Giles, UK) has been utilized for RT simulation for treatment planning. Planning CT images have been taken and then transferred to the delineation workstation (SimMD, GE, UK) for contouring of treatment volumes and surrounding critical structures. Either CT-simulation images only or fused CT and MR images have been used for the purpose of treatment volume definition for RT. Target determination with CT only and with incorporation of CT-MR fusion has been comparatively assessed. Synergy (Elekta, UK) linear accelerator (LINAC) has been used for treatment delivery with routine incorporation of Image Guided Radiation Therapy (IGRT) techniques with kilovoltage cone beam CT and electronic portal imaging.

\section{Results}

Precise RT planning has been performed by use of treatment planning systems at our tertiary cancer center. Optimal encompassing of treatment volumes with sparing of critical structures has been prioritized in RT planning to improve the therapeytic ratio. Definition of ground truth target volume has been done by the board certified radiation oncologists following comprehensive evaluation, colleague peer review, collaboration, and ultimate consensus to be utilized for actual treatment and for comparative assessments. Synergy (Elekta, UK) LINAC has been utilized for RT delivery. Target determination by CT-only imaging and by CT-MR fusion based imaging has been comparatively evaluated. As a result, ground truth target volume has been found to be identical with target volume definition with CTMR fusion based imaging.

\section{DISCUSSION}

Orbital RMS constitutes the most frequent soft tissue sarcoma in the head and neck region in children, and the prognosis may be rather favorable with contemporary therapeutic approaches [1-3]. Given the young patient population with long life expectancy, adverse effects of delivered therapies should be thoroughly considered for optimal management. Within this context, every effort should be made to improve the toxicity profile of treatment for this vulnerable patient population. Proton therapy has been introduced as a viable radiotherapeutic modality for improving the therapeutic ratio for patients suffering from orbital RMS [4-7].

Optimal sparing of critical structures and surrounding normal tissues is an important aspect of current RT practice in the era of state of the art therapies. Accurate target and treatment volume determination has been an area of extensive investigation to improve the therapeutic ratio. There has been unprecedented progress recently with considerable advances in radiation oncology discipline thanks to introduction of adaptive irradiation strategies along with excellent treatment delivery techniques with incorporation of Intensity Modulated Radiation Therapy (IMRT), Image Guided Radiation Therapy (IGRT), Adaptive Radiation Therapy (ART), Breathing Adapted Radiation Therapy (BART), automatic segmentation techniques, molecular imaging methods, and stereotactic irradiation strategies [8-43]. Regarding radiotherapeutic management of orbital RMS, promising results have been achieved by use of proton therapy [4-7]. Nevertheless, accurate treatment volume determination composes a more important part of state of the art therapeutic approaches given the introduction of recent treatment techniques and contemporary equipment. Excellent technologies including radiosurgical techniques may provide focused irradiation of well defined targets under stereotactic immobilization and image guidance to further improve precision and accuracy of radiotherapeutic management, however, target determination is very important given the typically high doses of irradiation given in a single or a few fractions with radiosurgery. From this standpoint, optimization of target and treatment volume definition is a critical aspect of RT for orbital embyonal RMS. Current IGRT techniques may offer improvements in target localization, and combined use of fused CT and MR images may significantly aid in precise target definition for accurate irradiation. In the literature, there have 
been many studies addressing the utilization of multimodality imaging for RT target definition [44-63]. We believe that our study may add to existing literature by addressing of multimodality imaging for target definition of orbital embryonal RMS.

In conclusion, combined use of CT and MRI for accurate target and treatment volume determination procedure may be considered to improve the therapeutic ratio for orbital embryonal RMS management with RT despite the need for further supporting evidence.

\section{REFERENCES}

[1] Tang LY, Zhang MX, Lu DH, Chen YX, Liu $Z G$, et al. (2018) The prognosis and effects of local treatment strategies for orbital embryonal rhabdomyosarcoma: a population-based study. Cancer Manag Res 10: 1727-1734.

[2] Jurdy L, Merks JH, Pieters BR, Mourits MP, Kloos RJ, et al. (2013) Orbital rhabdomyosarcomas: A review. Saudi J Ophthalmol 27: 167-75.

[3] Karcioglu ZA, Hadjistilianou D, Rozans M, DeFrancesco S (2004) Orbital rhabdomyosarcoma. Cancer Control 11: 328-333.

[4] Indelicato DJ, Rotondo RL, Mailhot Vega RB, Uezono H, Bradfield S, et al. (2019) 45 GyRBE for group III orbital embryonal rhabdomyosarcoma. Acta Oncol 58: 1404-1409.

[5] Yock T, Schneider R, Friedmann A, Adams J, Fullerton B, et al. Proton radiotherapy for orbital rhabdomyosarcoma: clinical outcome and a dosimetric comparison with photons. Int $\mathbf{J}$ Radiat Oncol Biol Phys 63: 1161-1168.

[6] Hug EB, Adams J, Fitzek M, De Vries A, Munzenrider JE (2000) Fractionated, threedimensional, planning-assisted proton-radiation therapy for orbital rhabdomyosarcoma: a novel technique. Int J Radiat Oncol Biol Phys 47: 979-984.

[7] Ladra MM, Edgington SK, Mahajan A, Grosshans D, Szymonifka J, et al. (2014) A dosimetric comparison of proton and intensity modulated radiation therapy in pediatric rhabdomyosarcoma patients enrolled on a prospective phase II proton study. Radiother Oncol 113: 77-83.

[8] Sager O, Dincoglan F, Demiral S, Uysal B, Gamsiz H, et al. (2020) Adaptive radiation therapy of breast cancer by repeated imaging during irradiation. World J Radiol 12: 68-75.

[9] Sager O, Dincoglan F, Demiral S, Uysal B, Gamsiz H, et al. (2019) Utility of Molecular Imaging with 2-Deoxy-2-[Fluorine-18] FluoroDGlucose Positron Emission Tomography (18F-FDG PET) for Small Cell Lung Cancer
(SCLC): A Radiation Oncology Perspective. Curr Radiopharm 12: 4-10.

[10] Sager O, Dincoglan F, Demiral S, Uysal B, Gamsiz H, et al. (2019) Breathing adapted radiation therapy for leukemia relapse in the breast: A case report. World J Clin Oncol 10: 369-374.

[11] Sager O, Dincoglan F, Uysal B, Demiral S, Gamsiz H, et al. (2018) Evaluation of adaptive radiotherapy (ART) by use of replanning the tumor bed boost with repeated computed tomography (CT) simulation after whole breast irradiation (WBI) for breast cancer patients having clinically evident seroma. Jpn J Radiol 36: 401-406.

[12] Sager O, Dincoglan F, Uysal B, Demiral S, Gamsiz H, et al. (2017) Splenic Irradiation: A Concise Review of the Literature. J App Hem B1 Tran 1: 101.

[13] Sager O, Beyzadeoglu M, Dincoglan F, Demiral S, Uysal B, et al. (2015) Adaptive splenic radiotherapy for symptomatic splenomegaly management in myeloproliferative disorders. Tumori 101: 8490.

[14] Ozsavaş EE, Telatar Z, Dirican B, Sager O, Beyzadeoğlu M (2014) Automatic segmentation of anatomical structures from CT scans of thorax for RTP. Comput Math Methods Med 2014: 472890.

[15] Dincoglan F, Beyzadeoglu M, Sager O, Oysul K, Kahya YE, et al. (2013) Dosimetric evaluation of critical organs at risk in mastectomized left-sided breast cancer radiotherapy using breath-hold technique. Tumori 99: 76-82.

[16] Sager O, Beyzadeoglu M, Dincoglan F, Oysul K, Kahya YE, et al. (2012) Evaluation of active breathing control-moderate deep inspiration breath-hold in definitive non-small cell lung cancer radiotherapy. Neoplasma 59: 333-340.

[17] [Sağer Ö, Dinçoğlan F, Gamsiz H, Demiral S, Uysal B, et al. (2012) Evaluation of the impact of integrated [18f]-fluoro-2-deoxy-D-glucose positron emission tomography/computed tomography imaging on staging and radiotherapy treatment volume definition of nonsmall cell lung cancer. Gulhane Med J 54: 220-227.

[18] [Sager O, Beyzadeoglu M, Dincoglan F, Oysul K, Kahya YE, et al. (2012) The Role of Active Breathing Control-Moderate Deep Inspiration Breath-Hold (ABC-mDIBH) Usage in nonMastectomized Left-sided Breast Cancer Radiotherapy: A Dosimetric Evaluation UHOD - Uluslararasi Hematoloji-Onkoloji Dergisi 22: 147-155.

[19] Sager O, Beyzadeoglu M, Dincoglan F, Demiral S, Gamsiz H, et al. (2020) 
Multimodality management of cavernous sinus meningiomas with less extensive surgery followed by subsequent irradiation: Implications for an improved toxicity profile. $\mathbf{J}$ Surg Surgical Res 6: 056-061.

[20] Beyzadeoglu M, Sager O, Dincoglan F, Demiral S, Uysal B, et al. (2020) Single Fraction Stereotactic Radiosurgery (SRS) versus Fractionated Stereotactic Radiotherapy (FSRT) for Vestibular Schwannoma (VS). J Surg Surgical Res 6: 062-066.

[21] Dincoglan F, Beyzadeoglu M, Sager O, Demiral S, Uysal B, et al. (2020) A Concise Review of Irradiation for Temporal Bone Chemodectomas (TBC). Arch Otolaryngol Rhinol 6: 016-020.

[22] Dincoglan F, Sager O, Uysal B, Demiral S, Gamsiz H, et al. (2019) Evaluation of hypofractionated stereotactic radiotherapy (HFSRT) to the resection cavity after surgical resection of brain metastases: A single center experience. Indian J Cancer 56: 202-206.

[23] Dincoglan F, Sager O, Demiral S, Gamsiz H, Uysal B, et al. (2019) Fractionated stereotactic radiosurgery for locally recurrent brain metastases after failed stereotactic radiosurgery. Indian J Cancer 56: 151-156.

[24] Demiral S, Dincoglan F, Sager O, Uysal B, Gamsiz H, et al. (2018) Contemporary Management of Meningiomas with Radiosurgery. Int J Radiol Imaging Technol 80: 187-190.

[25] Dincoglan F, Sager O, Demiral S, Uysal B, Gamsiz H, et al. (2017) Radiosurgery for recurrent glioblastoma: A review article. Neurol Disord Therap 1: 1-5.

[26] Demiral S, Dincoglan F, Sager O, Gamsiz H, Uysal B, et al. (2016) Hypofractionated stereotactic radiotherapy (HFSRT) for who grade I anterior clinoid meningiomas (ACM). Jpn J Radiol 34: 730-737.

[27] Gamsiz H, Beyzadeoglu M, Sager O, Demiral S, Dincoglan F, et al. (2015) Evaluation of stereotactic body radiation therapy in the management of adrenal metastases from nonsmall cell lung cancer. Tumori 101: 98-103.

[28] Sager O, Dincoglan F, Beyzadeoglu M (2015) Stereotactic radiosurgery of glomus jugulare tumors: Current concepts, recent advances and future perspectives. CNS Oncol 4: 105-114.

[29] Dincoglan F, Beyzadeoglu M, Sager O, Demiral S, Gamsiz H, et al. (2015) Management of patients with recurrent glioblastoma using hypofractionated stereotactic radiotherapy. Tumori 101: 179-184.

[30] Demiral S, Beyzadeoglu M, Sager O, Dincoglan F, Gamsiz H, et al. (2014)
Evaluation of Linear Accelerator (Linac)-Based Stereotactic Radiosurgery (Srs) for the Treatment of Craniopharyngiomas. UHODUluslararasi Hematoloji Onkoloji Dergisi 24(2): 123-129.

[31] Gamsiz H, Beyzadeoglu M, Sager O, Dincoglan F, Demiral S, et al. (2014) Management of pulmonary oligometastases by stereotactic body radiotherapy. Tumori 100: 179-183.

[32] Demiral S, Beyzadeoglu M, Sager O, Dincoglan F, Gamsiz H, et al. (2014) Evaluation of linear accelerator (linac)-based stereotactic radiosurgery (srs) for the treatment of craniopharyngiomas. UHOD - Uluslararasi Hematoloji-Onkoloji Dergisi 24: 123-129.

[33] Dincoglan F, Sager O, Gamsiz H, Uysal B, Demiral S, et al. (2014) Management of patients with $\geq 4$ brain metastases using stereotactic radiosurgery boost after whole brain irradiation. Tumori 100: 302-306.

[34] Sager O, Beyzadeoglu M, Dincoglan F, Gamsiz H, Demiral S, et al. (2014) Evaluation of linear accelerator-based stereotactic radiosurgery in the management of glomus jugulare tumors. Tumori 100: 184-188.

[35] Sager O, Beyzadeoglu M, Dincoglan F, Uysal B, Gamsiz H, et al. (2014) Evaluation of linear accelerator (LINAC)-based stereotactic radiosurgery (SRS) for cerebral cavernous malformations: A 15-year single-center experience. Ann Saudi Med 34: 54-58.

[36] Sager O, Beyzadeoglu M, Dincoglan F, Demiral S, Uysal B, et al. (2013) Management of vestibular schwannomas with linear accelerator-based stereotactic radiosurgery: a single center experience. Tumori 99: 617-622.

[37] Dincoglan F, Beyzadeoglu M, Sager O, Uysal B, Demiral S, et al. (2013) Evaluation of linear accelerator-based stereotactic radiosurgery in the management of meningiomas: A single center experience. J BUON 18: 717-722.

[38] Demiral S, Beyzadeoglu M, Uysal B, Oysul K, Kahya YE, et al. (2013) Evaluation of stereotactic body radiotherapy (SBRT) boost in the management of endometrial cancer. Neoplasma 60: 322-327.

[39] Dincoglan F, Sager O, Gamsiz H, Uysal B, Demiral S, et al. (2012) Stereotactic radiosurgery for intracranial tumors: A single center experience. Gulhane Med J 54: 190-198.

[40] Dincoglan F, Beyzadeoglu M, Sager O, Oysul K, Sirin S et al. (2012) Image-guided positioning in intracranial non-invasive stereotactic radiosurgery for the treatment of brain metastasis. Tumori 98: 630-635. 
[41] Sirin S, Oysul K, Surenkok S, Sager O, Dincoglan F, et al. (2011) Linear acceleratorbased stereotactic radiosurgery in recurrent glioblastoma: A single center experience. Vojnosanit Pregl 68: 961-966.

[42] Demiral S, Sager O, Dincoglan F, Uysal B, Gamsiz H, et al. (2021) Evaluation of breathing-adapted radiation therapy for rightsided early stage breast cancer patients. Indian J Cancer 2021. doi: 10.4103/ijc.IJC_140_19. (Online ahead of print)

[43] Sager O, Dincoglan F, Demiral S, Uysal B, Gamsiz H, et al. (2021) Omission of Radiation Therapy (RT) for Metaplastic Breast Cancer (MBC): A Review Article. International Journal of Research Studies in Medical and Health Sciences 6: 10-15.

[44] Demiral S, Sager O, Dincoglan F, Uysal B, Gamsiz H, et al. (2018) Evaluation of Target Volume Determination for Single Session Stereotactic Radiosurgery (SRS) of Brain Metastases. Canc Therapy \& Oncol Int J 12: 555848 .

[45] Sager O, Dincoglan F, Demiral S, Gamsiz H, Uysal B, et al. (2019) Utility of Magnetic Resonance Imaging (Imaging) in Target Volume Definition for Radiosurgery of Acoustic Neuromas. Int J Cancer Clin Res 6: 119.

[46] Sager O, Dincoglan F, Demiral S, Beyzadeoglu M (2019) Evaluation of Radiosurgery Target Volume Determination for Meningiomas Based on Computed Tomography (CT) And Magnetic Resonance Imaging (MRI). Cancer Sci Res Open Access 5: 1-4.

[47] Dincoglan F, Sager O, Demiral S, Beyzadeoglu $M$ (2019) Multimodality Imaging for Radiosurgical Management of Arteriovenous Malformations. Asian Journal of Pharmacy, Nursing and Medical Sciences 7: 7-12.

[48] Beyzadeoglu M, Sager O, Dincoglan F, Demiral S (2019) Evaluation of Target Definition for Stereotactic Reirradiation of Recurrent Glioblastoma. Arch Can Res 7: 3.

[49] Sager O, Dincoglan F, Demiral S, Gamsiz H, Uysal B, et al. (2019) Evaluation of the Impact of Magnetic Resonance Imaging (MRI) on Gross Tumor Volume (GTV) Definition for Radiation Treatment Planning (RTP) of Inoperable High Grade Gliomas (HGGs). Concepts in Magnetic Resonance Part A 2019, Article ID 4282754.

[50] Demiral S, Sager O, Dincoglan F, Beyzadeoglu M (2019) Assessment of target definition based on Multimodality imaging for radiosurgical Management of glomus jugulare tumors (GJTs). Canc Therapy \& Oncol Int J 15: 555909 .
[51] Demiral S, Sager O, Dincoglan F, Beyzadeoglu M (2019) Assessment of Computed Tomography (CT) And Magnetic Resonance Imaging (MRI) Based Radiosurgery Treatment Planning for Pituitary Adenomas. Canc Therapy \& Oncol Int J 13: 555857.

[52] Dincoglan F, Sager O, Demiral S, Beyzadeoglu M (2019) Incorporation of Multimodality Imaging in Radiosurgery Planning for Craniopharyngiomas: An Original Article. SAJ Cancer Sci 6: 103.

[53] Sager O, Dincoglan F, Demiral S, Beyzadeoglu M (2020) Evaluation of Target Volume Determination for Irradiation of Pilocytic Astrocytomas: An Original Article. ARC Journal of Cancer Science 6: 1-5.

[54] Demiral S, Beyzadeoglu M, Dincoglan F, Sager O (2020) Evaluation of Radiosurgery Target Volume Definition for Tectal Gliomas with Incorporation of Magnetic Resonance Imaging (MRI): An Original Article. Biomedical Journal of Scientific \& Technical Research (BJSTR) 27: 20543-20547.

[55] Beyzadeoglu M, Dincoglan F, Demiral S, Sager O (2020) Target Volume Determination for Precise Radiation Therapy (RT) of Central Neurocytoma: An Original Article. International Journal of Research Studies in Medical and Health Sciences 5: 29-34.

[56] Sager O, Dincoglan F, Demiral S, Beyzadeoglu M (2020) Radiosurgery Treatment Volume Determination for Brain Lymphomas with and without Incorporation of Multimodality Imaging. Journal of Medical Pharmaceutical and Allied Sciences 9: 2398-2404.

[57] Demiral S, Beyzadeoglu M, Dincoglan F, Sager O (2020) Assessment of Target Volume Definition for Radiosurgery of Atypical Meningiomas with Multimodality Imaging. Journal of Hematology and Oncology Research 3: 14-21.

[58] Beyzadeoglu M, Dincoglan F, Sager O, Demiral S (2020) Determination of Radiosurgery Treatment Volume for Intracranial Germ Cell Tumors (GCTS). Asian Journal of Pharmacy, Nursing and Medical Sciences 8: 18-23.

[59] Sager O, Demiral S, Dincoglan F, Beyzadeoglu M (2020) Target Volume Definition for Stereotactic Radiosurgery (SRS) Of Cerebral Cavernous Malformations (CCMs). Canc Therapy \& Oncol Int J 15: 555917.

[60] Dincoglan F, Demiral S, Sager O, Beyzadeoglu M (2020) Utility of Multimodality Imaging Based Target Volume Definition for Radiosurgery of Trigeminal Neuralgia: An Original Article. Biomed J Sci \& Tech Res 26: 19728-19732. 
[61] Dincoglan F, Beyzadeoglu M, Demiral S, Sager O (2020) Assessment of Treatment Volume Definition for Irradiation of Spinal Ependymomas: an Original Article. ARC Journal of Cancer Science 6: 1-6.

[62] Sager O, Dincoglan F, Demiral S, Beyzadeoglu M (2020) Evaluation of Treatment Volume Determination for Irradiation of chordoma: an
Original Article. International Journal of Research Studies in Medical and Health Sciences 5 (10): 3-8

[63] Sager O, Dincoglan F, Demiral S, Beyzadeoglu M (2020) Assessment of Target Volume Definition for Irradiation of Hemangiopericytomas: An Original Article. Canc Therapy \& Oncol Int J 17(2).

Citation: FerratDincoglan,Omer Sager, Selcuk Demiral, Murat Beyzadeoglu, Target Definitionoforbital Embryonal Rhabdomyosarcoma (Rms) by Multimodality Imaging: An Original Article. ARC Journal of Cancer Science. 2020; 6(2):12-17. DOI:dx.doi.org/ 10.20431/2455-6009.0602003.

Copyright: (C) 2020 Authors. This is an open-access article distributed under the terms of the Creative Commons Attribution License, which permits unrestricted use, distribution, and reproduction in any medium, provided the original author and source are credited. 